\title{
Ontological politics of hydrosocial territories in the Salween
}

River basin, Myanmar/Burma

\section{Götz, Johanna M.}

2020-04

Götz , J M \& Middleton , C 2020 , ' Ontological politics of hydrosocial territories in the Salween River basin, Myanmar/Burma ' , Political Geography , vol. 78 , 102115 . https://doi.org/10.1016/j.polgeo.201

http://hdl.handle.net/10138/337382

https://doi.org/10.1016/j.polgeo.2019.102115

cc_by_nc_nd

acceptedVersion

Downloaded from Helda, University of Helsinki institutional repository.

This is an electronic reprint of the original article.

This reprint may differ from the original in pagination and typographic detail.

Please cite the original version. 


\title{
Ontological politics of hydrosocial territories in the Salween River basin, Myanmar/Burma
}

\author{
Johanna M. Götz ${ }^{\mathrm{a}}$, Carl Middleton ${ }^{\mathrm{b}, *}$

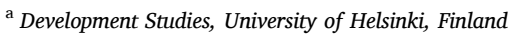 \\ ${ }^{\mathrm{b}}$ Center of Excellence on Resource Politics for Social Development, Center for Social Development Studies, Faculty of Political Science, Chulalongkorn University, \\ Bangkok, Thailand
}

\section{A R T I C L E I N F O}

\section{Keywords:}

Salween/Thanlwin River

Resource politics

Multiple ontologies of water

Partially-connected worlds

\begin{abstract}
A B S T R A C T
In this paper, we question an often-unchallenged assumption that we all talk about the same 'thing' when talking about water. Taking the Salween River in Myanmar as a case study, we draw on a growing body of hydrosocial literature to analyze the multiple ontologies of water. Conceptually, we take each ontology to be constituted of and enacted within - a human-more-than-human assemblage, the spatiotemporal dimensions of which demarcate a 'hydrosocial territory.' We present three illustrations, namely: the role of the Union Government's National Water Resources Committee and how it manifests and is situated within an ontology of 'modern Water'; a Karen indigenous initiative to establish a Salween Peace Park and an associated revealing of an 'indigenous' ontology; and plans for the construction of mainstream hydropower dams and electricity export to neighboring Thailand, where different water ontologies and their hydrosocial territories collide. We examine how multiple ontologies of water are contested through 'ontological politics', whereby human actors compete to further their own interests by naturalizing their ontology while marginalizing others. While not downplaying the role violent conflict plays, we argue that in the Salween basin ontological politics are an underappreciated terrain of contestation through which political authority and the power relations that underpin it are (re)produced, with implications for processes of state formation, territorialization and the ongoing peace negotiations.
\end{abstract}

\section{Introduction}

In recent years, there has been considerable scholarly effort to reconceptualize water-society relations, and to question the dualistic notion placing Nature, including Water, outside of the realm of Society ${ }^{1}$ and vice versa. 'Hydrosocial' research emphasizes that water and society are internally relational (Linton \& Budds, 2014; Wesselink, Kooy, \& Warner, 2017) and are thus human-more-than-human assemblages of 'hybrid water' (Swyngedouw, 2004). The hydrosocial literature has also paid attention to the spatial dimensions of these assemblages, which Boelens, Hoogesteger, Swyngedouw, Vos, and Wester (2016) refer to as 'hydrosocial territories.'

In many river basins, the politics of water are important to processes of territorialization and state formation (Hoogesteger, Boelens, \& Baud,
2016), as well as to the (re)production of political authority and associated power relations (Obertreis, Moss, Mollinga, \& Bichsel, 2016). In this paper, we draw on a hydrosocial approach to analyze the complex political geography and contested processes of state formation of the Salween River in Eastern Myanmar. ${ }^{2}$ Until today, Myanmar's Union Government does not hold full sovereignty over the whole of the basin (Walton, 2018). In the ethnic-minority dominated States through which the Salween flows, there are highly fragmented, overlapping networks of actors - including, inter alia, the Myanmar Union government; the Tatmadaw (the Myanmar Armed Forces); Ethnic Armed Organizations (EAOs); and domestic and foreign private investors - which contest political authority, legitimacy and sovereignty over at times overlapping territorial spaces and associated 'Natural Resources' (Burke, Williams, Baroon, Jolliffe, \& Carr, 2017). Therefore, narrating the political

\footnotetext{
* Corresponding author. Faculty of Political Science, 2nd Floor, Building 2, Henri-Dunant Road, Pathumwan, Bangkok, 10330, Thailand.

E-mail addresses: johanna.goetz@helsinki.fi (J.M. Götz), carl.chulalongkorn@gmail.com (C. Middleton).

1 We refer to Moore's (2015) use of Nature (with a capitalized 'N') as used within a dualist understanding and in relation with an independent unit Society (with a capitalized ' $S$ ').

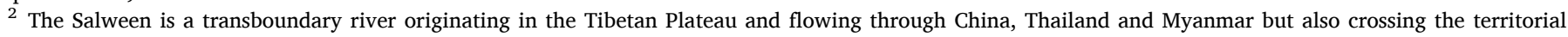
borders of four States within Burma, namely Shan, Karenni, Karen and Mon States.
} 
geography of the Salween basin is a challenging task, reflecting the complexity of the multiple interpretations and knowledges of events, asymmetric power relations, and the ontological situatedness of the narrators.

Hydrosocial thinking has been especially strong in critically scrutinizing the political implications of 'modern' Water that reduces it to its mere material, physical dimensions, namely $\mathrm{H}_{2} \mathrm{O}$, and rendering Water separate from Society (Linton, 2010). This dualistic modern ontology enables for Water's technical management based on claims of 'neutral' scientific principles such as 'Integrated Water Resources Management' (IWRM) and is also the foundation of an economic logic through which Water may become commoditized (Linton \& Budds, 2014). Many have critiqued IWRM's claims of scientific neutrality (Molle, 2008), and highlighted the potential social justice implications of Water's commodification (Bakker, 2007). Far from neutral, claiming water as $\mathrm{H}_{2} \mathrm{O}$ is a profound assertion of political power.

However, Water - emergent as it is from a particular assemblage - is one of many forms hybrid water may take. Linton and Budds (2014:175) observe that "different kinds of waters are realized in different hydrosocial assemblages; [For example] in one such assemblage, water is constituted as a public good, while in another, it is constituted as a commodity." Moreover, Boelens et al. (2016:4) write, "it is common to find worldviews ... that express how water possesses many properties and faces: powerful, productive, destructive; engineered, natural and supernatural." By emphasizing the multiplicity of waters, a fundamental question arises: When different groups talk about a river, are they talking about the same 'thing'?

In this paper, we take as a starting point debates around multiple ontologies of water, influenced by political anthropology amongst other academic fields (Barnes \& Alatout, 2012; Yates, Harris, \& Wilson, 2017). We focus on the Salween River which, comparative to other rivers of the region, is relatively less researched and 'known' (Middleton \& Lamb, 2019). Overall, we explore how multiple ontologies of the Salween have been enacted and become revealed, in whose interests they serve, and what the implications are for contested state formation via the production of hydrosocial territories and the (re)production of political authority. To do so, we analyze three illustrations to reveal how multiple ontologies of water may become enacted and contested. The first illustration is the institutionalization and policy-making of Myanmar's National Water Resources Committee (NWRC), and its 'ontological work' enacting a modernist ontology of Water in a national framework. The second illustration is the formation of the Salween Peace Park situated in an 'indigenous' ontology of water. ${ }^{3}$ The third illustration is the ongoing proposals for mainstream hydropower dams, where we see the contested claims for the meaning of the river and the political authority/legitimacy to make decisions towards it as part of 'ontological politics'. ${ }^{4}$

Overall, we argue that in order to better understand the competing fragmented sovereignties within Myanmar's ethnic states, analysis should not only focus on the physical and often violent contestation over resources and territories between the Tatmadaw and EAOs, and the typically opaque pursuit of commercial interests by Thai and Myanmar private actors. Rather, recognizing that in the Salween basin's 'resource politics' some ontologies emerge as dominant and others are marginalized, the processes of ontological politics may legitimize particular claims for state formation and territorialization to the benefit of those

\footnotetext{
${ }^{3}$ We refer to an 'indigenous' ontology, but are painfully aware of the term's limitations. Yet, we find it preferable to other commonly used terms (local; folk; traditional; situational etc.) as it is used as self-prescription within relevant documents (e.g. SPP Charter; KNU Land Policy).

${ }^{4}$ See Middleton et al. (2019) and Lamb et al. (2019) for maps of the Salween basin and proposed hydropower projects.
}

with greater power. ${ }^{5}$ Thus, whilst not downplaying the role violent conflict plays, attention should also be paid to the 'ontological work' involved in establishing a particular way of 'how things are' or how things should be, including who undertakes this work and to what ends, as claims for (legitimate) political authority are also at stake. Throughout this paper, we draw out how ontological politics both reflect underlying power-relations of different actors and portray wider political and territorial claims within the complexities of the Salween through contested multiple waters. At stake are the ongoing peace negotiations, including the form of federalism that may emerge, and therefore also the future of the Salween River.

In the next section, we survey recent literature from political anthropology on multiple ontologies (of water) and ontological politics, and relate this to the hydrosocial literature and in particular regarding hydrosocial territories. We then present in detail the three illustrations and finally offer a synthesis analysis and conclusion. The article draws upon insights gained during a three-year project on the Salween River that included extensive literature review and report writing, a range of interviews and informal conversations, a series of meetings and conferences, and support to thirteen research fellowship projects (see (Middleton and Lamb, 2019). It also draws on the MA thesis of the first author that involved fieldwork in Yangon, Hpa-An and beyond, including, inter alia, document analysis and interviews with key informants.

\section{Ontological politics and the production of hydrosocial territories}

\subsection{Multiple ontologies and ontological politics}

We take as our point of departure that instead of a single, untouchable reality 'out there', there are multiple existing, historically, culturally and materially embedded realities (or ontologies/worlds) (Mol, 1999; Blaser, 2009). ${ }^{6}$ Yet, grasping ontology - or rather ontologies - is far from straightforward. Ontology must not be understood as predefined and static, but rather as Mol (1999:77) understands, "a reality [that] is done and enacted rather than observed". Furthermore, rather than defining one (or many) ultimate reality(ies), the focus is shifted towards questioning how "relationalities are revealed and structured" (Joronen \& Häkli, 2016, p. 6). ${ }^{7}$ Thus, multiple ontologies can be studied and understood as "ways of worlding" (Blaser, 2013), "worldly practices", "events of revealing" (Joronen \& Häkli, 2016) or as "total enactments involving discursive and non-discursive aspects" (Blaser, 2009, p. 877; also; Mol, 1999).

Thus, rather than seeking to authoritatively determine what water (and the Salween) is for different groups of actors (Linton \& Budds, 2014, p. 179), we trace the human-more-than-human assemblages that reflect different waters. Thereby, we focus on the performance of groups of actors within these networks to examine the ways multiple realities (or ontologies) of water(s) become enacted, including how these actors situate themselves within these networks of human-more-than-human

\footnotetext{
${ }^{5}$ We appreciate the input of two anonymous reviewers who assisted our paper's focus.

6 With this assertion, we do not intend to disavow the singularizing modern ontology by replacing it with another singularizing meta-ontology (see Blaser, 2013).

7 This includes our own situatedness as authors of this text. We are very aware of our own limitations and that we, as authors, are part of this enactment and thus part of configuring and (often unconsciously) reinforcing the ontologies we are socialized in.
} 
relationships. ${ }^{8}$ By acknowledging multiple waters as enacted and in continuous processes of reality-making, we hold that reality is not pre-given. Rather, multiple ontologies are in contestation for their existence wherein some become dominant and others marginalized through processes of 'ontological politics'.

For the purpose of this paper, we build upon previous work (e.g. De la Cadena, 2015; Blaser, 2009) and define ontological politics as the contestation between different groups enacting worlds situated in different ontologies. Importantly, this involves the creation and sustaining of one world and - in the process - the denial of others (De la Cadena, 2015) as well as associated underlying and resulting power-relations. We see this simultaneous process of creation and denial as 'ontological work' that entails the deployment of effort and various forms of power to these ends, including material and institutional resources, knowledge, discourses, and (threat of) violence, as commonly analyzed in the field of political ecology (e.g. Robbins, 2012). As a highly political outcome, the ontology of dominant, more powerful actors tends to become naturalized, whilst the ontologies of others are marginalized.

\subsection{Spatializing multiple ontologies: hydrosocial territories}

The enactments of ontologies are also part of processes of continuous territorialization, given that the associated making of human-morethan-human relations hold spatial and scalar dimensions. Through the lens of hydrosocial territories, processes of territorialization occur around water(s). Boelens et al. (2016:2) conceptualize a hydrosocial territory as:

... the contested imaginary and socio-environmental materialization of a spatially bound multi-scalar network in which humans, water flows, ecological relations, hydraulic infrastructure, financial means, legal-administrative arrangements and cultural institutions and practices are interactively defined, aligned and mobilized through epistemological belief systems, political hierarchies and naturalizing discourses.

Whilst in much of this literature, ontologies are not directly identified as performative in the constitution of hydrosocial territories, many of the above processes and factors are suggestive of ontological enactment. For example, Boelens et al. (2016:3) write how "[creating] hydrosocial territories involves humanizing nature and building humanized waters based on social, political and cultural visions of the world-that-is and the world-that-should-be ... Therefore the (re)creation of hydrosocial territories (and water) needs to be analyzed in the context of their historical, cultural and political settings". What interests us then is the ontological dimension that enacts and reveals those creating processes. For instance, based on which ontological groundings is the 'world-that-should-be' imagined?

Territories are not pre-given; rather, they are the active political organization of space through "... interweaving its biophysical and social qualities" (Hoogesteger et al., 2016, p. 92). The formation or claim of territory fundamentally relates to claims for legitimacy and political authority to govern. Territorial pluralism emerges where "diverse territories are overlapping, interacting and conflicting in one and the same geographical-political space" (Hoogesteger et al., 2016, p. 93; also; Boelens et al., 2016). Hoogesteger et al. (2016) go on to observe that

\footnotetext{
8 There is some similarity between our understanding of situatedness and that of Li (2000), who in her ethnographic work in Indonesia draws on Stuart Hall to consider the positioning of groups as tribal or indigenous that emerges through processes of struggle that are "the contingent products of agency and the cultural and political work of articulation" (Li, 2000, p. 151). Similar to our understanding of ontology, for $\mathrm{Li}$ (2000) indigenous/tribal identities are continually "becoming." This paper differs, however, with our broader focus on ontology vis-à-vis Li's focus on identity.
}

these “... 'territories-in-territory' have partially different, partially similar building blocks, but these are patterned in different and sometimes opposing ways, configurations and meanings ... Therefore, different 'territories-in-territory' are structured by different rules and normative frameworks, sources of legitimacy, forms of authority and related discourses."

Such an insight links to our conceptualization above of multiple ontologies, and in particular how territories interrelate and overlap. Here, we follow De la Cadena (2015), who emphasizes the way worlds are intertwined or "partially connected" and thereby never reducible to either one. If we approach ontology as such, what Blaser \& De la Cadena (2018) have named the "pluriverse", opens up:

... the practice of a world of many worlds, or what we call a pluriverse: heterogeneous worldings coming together as a political ecology of practices, negotiating their difficult being together in heterogeneity. (Blaser \& De la Cadena, 2018:4)

In their spatiotemporal manifestation, these worlds reveal themselves in (hydrosocial) territorial pluralism.

\section{The ontological politics of hydrosocial territories in the Salween basin}

\subsection{Illustration 1: The National Water Resources Committee and its situatedness in a 'modern' Water}

[The National Water Resources Committee] should be a legislative body in national water sector [sic] and should have authorization [sic] of the government to play a significant role in any national/ state level water use (scheme or programme) of consumptive or nonconsumptive nature. (NWRC, 2015:46)

This extract from the National Water Policy (NWP) of Myanmar strikingly brings together claims for political authority, state formation and territorialization, and - as we will reveal in the following - a certain ontological situatedness.

With the transition towards a quasi-democratic system in Myanmar, a major restructuring of Union government institutions has unfolded since 2010 (Farrelly, Holliday, \& Simpson, 2018). Regarding water governance, a National Water Resources Committee (NWRC) was established by presidential degree in 2013 and reconstituted in March 2016 after the last elections. The NWRC is formed of 20 members from water-related state agencies, chaired by the Vice President, and has an Advisory Group (AG) made up of various 'water experts' (Aye Sapay Phyu, 2016). A key task of this Union-government mandated 'apex body' is to draft countrywide water-related rules and regulations, which has included the approved NWP and National Water Framework Directive (NWFD), and the - not yet publicly available - National Water Law. This is a challenging task given that the Union Government does not maintain full sovereignty over the country (Walton, 2018).

In this section, we reveal how these documents, the knowledge therein, and the actors and institutions who created them are enacting a world situated in an ontology of 'modern Water', namely an objectified, neutral $\mathrm{H}_{2} \mathrm{O}$ /Water embedded in and (co)productive of a universalized 'economic modernization' paradigm (Bakker, 2007; Linton, 2010). As a result, dominant hydrosocial territories are in the process of being produced predominantly scaled in-line with the modern nation-state. As revealed in the next two illustrations, however, these hydrosocial territories are far from uncontested.

The laws and policies drafted by the NWRC are framed by the IWRM paradigm, and thus draw on classical hydrological concepts, including the river basin as a basic hydrological unit, and the consideration of 'hydrological factors/facts' (Linton \& Budds, 2014) circling in the hydrological cycle (DWIR, 2015; NWRC, 2015). As Linton and Budds (2014:171) observe, "the hydrologic cycle ... is not merely a neutral scientific concept but can be regarded as a social construct with political 
consequences." This hydrological cycle framing is evident within the NWP:

All elements of the water cycle, i.e., evapotranspiration, precipitation, runoff, river, lakes, soil moisture, and groundwater, sea, etc., are interdependent and the basic hydrological unit is the river basin, which should be considered as the basic hydrological unit for planning. (NWRC, 2015:15)

What we can observe here is how Water as $\mathrm{H}_{2} \mathrm{O}$ becomes reflected in the ways knowledge is produced and worlds made through the NWRC. For instance, within the recently established Hydroinformatics Center under the NWRC, all "relevant hydrologic and water resources data" are to be quantified, collected and made publicly available "[in] order to promote efficient planning and implementation of water resources development projects" (NWRC, 2015, pp. 49-51). In this sense Water is made known, studied and represented in largely technical terms through reports, laws and scientific data collection, which is highly amenable to economic premises. It is produced of, and affirms, the power of 'the expert', and in particular the government-aligned 'expert'.

While IWRM is often proposed as a means to overcome silo-thinking in water management, it has been critically scrutinized for manifesting a Water/Society divide. As Linton and Budds (2014) note, by drawing out the need to integrate the hydrological dimension of Water with Society, an (imaginary) separation is made between the two. This gets further consolidated by the 'expert'-led water governance approaches IWRM is based upon, which make issues around water seem apolitical and manageable through a "problem-solving [that] can be informed by neutral and rational approaches, good science ... and expert knowledge" (Molle, 2008, p. 133) as resonating in Myanmar's NWP:

Inter-regional, inter-State, intra-State, as [sic] also inter-sectorial disputes in sharing of water, strain relationships and hamper the optimal utilization of water through scientific planning on basin/ sub-basin basis. (NWRC, 2015:6)

A revealing of $\mathrm{H}_{2} \mathrm{O}$ can depoliticize issues around water leading to claims that it ought to be managed and governed by 'technical' and 'apolitical' means through 'neutral' scientific principles (cf. Ferguson, 1994; Swyngedouw, 2013). In the process, as seen in Myanmar's NWP, Water more readily becomes "treated as economic good so as to promote its conservation and efficient use" (NWRC, 2015, p. 15). Overall, Water becomes enacted by and is simultaneously constitutive of a wider set of relations in an assemblage of 'modernization'. This includes the mentioned institutional and legal-administrative arrangements that tend to organize the material flows of and technologies around water and also territorial articulations as we will see shortly - based on a modern Water. Such an enactment of Water is an assertion of political power shaping decision-making processes and distributive outcomes. This bears in it the likelihood of rendering other ontologies and practices, present in the Salween basin, invisible.

To clarify, we can take the example of the development of the National Water Law where participation is said to be taking place "very wide and far" in which "everyone has to [be] involve[d]" (personal communication with NWRC AG member, 2017). Nevertheless, critics argue that only selected representatives are invited to meetings and their proposals are not being properly considered (personal communication with local CSO representative, 2017). As such, 'participating' in these consultative processes may legitimize centralized policy-making without having one's own voice represented in the 'final product'. In a similar vein, the environmental impact assessments (EIAs) for dam projects nowadays allow participation in Myanmar, however, only as long as the fundamental (modernist) grounding is not challenged. In line with this, Swyngedouw (2013:832) warns of the disavowal of antagonism through the widening formation of ' 'democratic' governance that nonetheless leaves fundamental issues and questions about how to frame socio-natural relations beyond dispute". Such a process of incorporation is ongoing in current global water governance practice and within the national water policy-making of Myanmar. In turn, it reproduces the political authority and power of the Union Government and an expert-led approach to water governance.

The NWRC with its enacting of claims situated in a dominant 'modern Water' ontology further points towards its assertion of political authority. This is manifested, for example, within the concepts used and policies published and its Union government-mandated position as 'apex body'. Political authority and legitimization are also generated through the use of global water policy and knowledge frameworks that facilitate its cooperation with global water agencies and nation-states (Warner, Wester, \& Bolding, 2008). Myanmar's water rules and regulations are clearly reflective of current hegemonic global water policy-making, namely IWRM, often referred to as 'international best practice' and produced by an array of dominant actors including other governments, international financial institutions, international non-governmental organizations (INGOs) and academics (Molle, 2008). IWRM in Myanmar can be traced back to engagements with global water policy institutions as for instance the involvement with the Global Water Partnership in Myanmar since at least 2003 (GWP, 2016). Much research, projects and writing on water to date in Myanmar also affirm an IWRM-centric lens and are largely commissioned for and in service of the Union government (e.g. Nesheim \& Platjouw, 2016). In summary, knowledge is produced by 'experts' and approved through powerful actors in political posts, namely ministers and the ruling government/elites at the Union level. However, while centralized government structures can be observed historically and in the present in Myanmar, they have never been comprehensively executed within the whole 'nation-state' and this is especially true for many areas within the Salween basin (Walton, 2018).

How does this revealing manifest territorially? Rather than a straightforward claim for territory, we can see how national water policy-making is implicitly staking claims and reinforcing certain spatial articulations, in particular that of the nation-state and the river basin (see Fig. 1) (cf. also Götz, 2019 for a discussion on scalar politics of water governance in Burma). It inter alia does so by relying on the hierarchical organization and the resultant enforced state territorialization practices of the modern state. As Hoogesteger et al. (2016:94) establish, “... administrative boundaries (nation, province, municipality, irrigation system) and procedures ... are enforced through hierarchically organized institutions in charge of managing water affairs ... The state 'steers water society' and consolidates its grip depending greatly on its techniques of territorial water governance." Relying on the premises of the modern state and an ontological grounding in a 'modern Water', one bounding of a hydrosocial territory becoming (re)enforced is thus Myanmar's international borders, which reflects a claim for political authority and legitimacy that the NWRC (and the Union Government) governs Water within a unified 'Union territory'. By implementing institutions and policies based on the nation-state, the NWRC actively takes part in the (continuous) process of nation-building. With the NWP claiming water within the states borders, which - as with other 'Resources' - is under the ownership of the Union according to the 2008 Constitution (Union of Myanmar, 2008), and also relating it to other nation-states via transboundary cooperation, water is being bound to a specific territorial imaginary and manifestation. Here, it is important to 


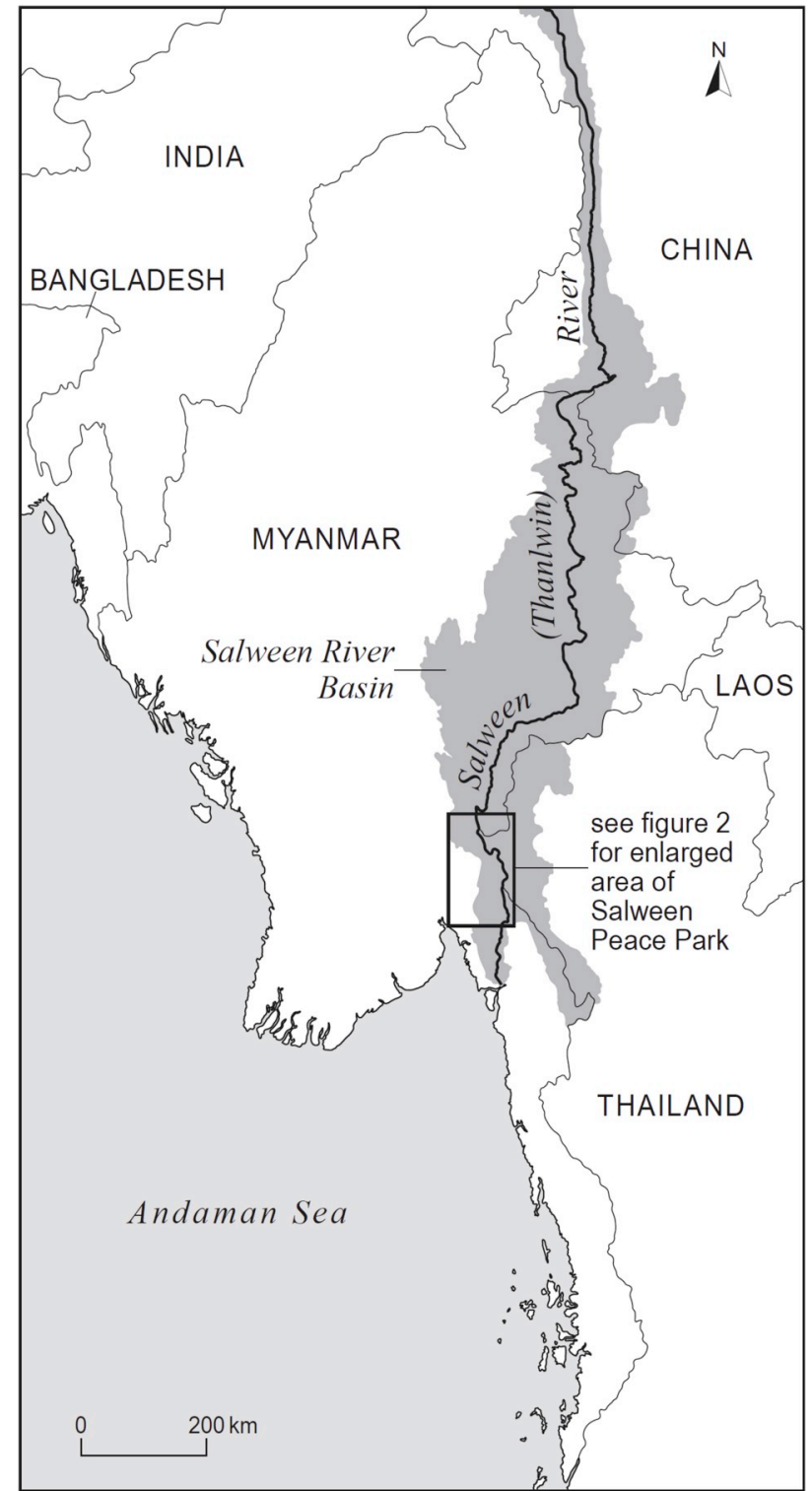

Fig. 1. Map of the Salween basin in the context of national borders. (Cartography by Chandra Jayasuriya, University of Melbourne, with permission).

note that as a government body the NWRC is ultimately bound to the current, highly-disputed 2008 Constitution $^{9}$ and thus also based on certain imaginaries/claims of how the Union ought to be administratively structured. For the NWRC, this predetermines Union-government defined territorial articulations where contesting political authorities and fragmented territorial claims are erased on-paper within the river basin - but not entirely on-the-ground, reflecting existing power relations between the Union Government and the various actors in ethnic areas. These political claims of the Union Government, however, do serve to centralize water both discursively and materially.

\footnotetext{
9 The referendum on the 2008 Constitution, held in May 2008 one week after Cyclone Nargis devastated Myanmar, was widely regarded as a sham. The 2008 Constitution introduced a national-level upper and lower house (Hluttaw), separated the executive, judiciary, and legislative, and introduced a degree of decentralization. However, it maintains a significant role for the military including naming 25 percent of the seats in the upper and lower Hluttaw that ensures a veto power on key decisions (including changes to the constitution), selection of one vice-president, and appointment of ministers for three key ministries.
}

Closely connected, a second hydrosocial territory that becomes enacted is that of the 'river basin', which is the unit of management emphasized by IWRM (Molle, 2008). The multiple interrelated territorial claims around water by the NWRC are well captured in the following quote from the NWP:

Integrated Water Resources Management (IWRM) taking river basin / sub-basin as a unit should be the main principle for planning, development and management of water resources. The departments / organizations at Union/ Regional or State Governments levels should be restructured and made multi-disciplinary accordingly. (NWRC, 2015:45)

Taking the Salween River basin as a unit of governing brings into play a contradiction: On the one hand, this territorial claim is a political positioning within what is already a complex and highly disputed fragmentation of levels/territories, actors and political authorities around water. On the other hand, IWRM and the river basin imaginary taken by the NWRC tends to render water managerial and 'apolitical', downplaying the fragmentation within the 'basin' of contesting political authorities and legitimacies, and the multiple territorial articulations and ontologies associated with it. This might also be a partial reason why the NWRC has thus far emphasized its most significant work on the Ayeyarwady basin and has had little to no real influence along the Salween, as we will see in the next illustration. Nevertheless, national policies are aimed to work on a nation-wide scale and the recent engagement of ministerial bodies with the International Finance Corporation (IFC) to conduct a Strategic Environmental Assessment (SEA) of the hydropower sector in Myanmar (IFC, 2018), including on the Salween River, hint towards a claim to govern the Salween basin in the absence of a political agreement for peace. ${ }^{10}$

\subsection{Illustration 2: The Salween Peace Park: enacting indigenous ontologies}

Let us travel up the Salween River to Karen State's Mutraw District ${ }^{11}$ and to the Salween Peace Park (SPP). Here, a network of actors including community representatives, local leadership of the EAO the Karen National Union (KNU), ${ }^{12}$ and members of the civil society organization the Karen Environmental and Social Action Network (KESAN) push for their own vision over an area of more than $5000 \mathrm{~km}^{2}$, which encloses a range of community and reserved forests, wildlife sanctuaries and identified customary land (KNU \& KESAN, 2016; SPP GC, 2019; cf. Fig. 2). KESAN, in turn, also works within networks of civil society groups within Myanmar and beyond. While the process and work of what has become to be known as the SPP has been going on for over 15 years, the 'official' launch of the SPP including the proclamation of the SPP Charter took

\footnotetext{
${ }^{10}$ We note that voices and imaginaries within the NWRC and its AG are not unified. For instance, a Salween Policy has been proposed since 2017 by some members of the AG combining IWRM-based lines with more indigenous notions (personal communication, $2017 \& 2018$ ). To what extent these imaginaries will be able to accommodate multiple ontologies, and redistribute power, remains uncertain and will require more in-depth analysis.

11 Referred to as Mutraw District and Papun District in the Karen and Myanmar administrative system respectively. This already hints towards different territories-in-territory. While Papun District describes the 'official' administrative demarcation within Kayin State, the KNU has defined its very own Karen State Districts. Thereby, most of the demarcations vary tremendously from 'official' Union Districts and also States/Regions. Mutraw District, however, is almost congruent to Papun District.

${ }^{12}$ It is important to notice that the KNU with its armed wing, the KNLA, is much more than a mere armed resistance group. Rather, throughout its history of over six decades of armed resistance, the KNU has installed and - especially in more remote areas - sustained elaborate quasi-state like administrative and governance structures (for further elaboration see Jolliffe, 2016, 2017; Brenner, 2017).
} 
place in December 2018 (SPP Steering Committee \& KNU, 2018) and the first meeting of the General Assembly in April 2019 (SPP GC, 2019). We will see in the following how this territorial and political claim becomes enacted from an ontological situatedness that is rather divergent from the previous illustration. These actors envision a:

... grassroots, people-centered alternative to the previous Myanmar government and foreign companies' plans for destructive development in the Salween River basin. Instead of massive dams on the Salween River, we see small hydropower and decentralized solar power .... Instead of megaprojects that threaten conflict and perhaps the resumption of war, we seek a lasting peace and a thriving ecosystem where people live in harmony with the nature around them. (KNU \& KESAN, 2016:3)

These visions are based on a discourse that calls for a "bottom-up", "community-based" approach with traditional systems to be preserved and promoted. Thereby, the "local" people shall have "the right to selfgovernance", natural resources and wildlife shall be protected, and "Karen indigenous people's culture and life" are to be preserved (personal communication, 2017). This already hints towards a rather different territorialization project that is enacted from a local sense of belonging, and is an assertion of power derived from it.

A different ontological situatedness can be traced that carries with it an explicitly political approach to water, indicating how 'water' is loaded with both politics and emotions. Water is life. Water is political. These recurring articulations voiced by communities in anti-dam protests (e.g. KESAN, 2015) reflect the way water is understood and communicated in connection to the SPP. In contrast to the above introduced scientific rationale of water as $\mathrm{H}_{2} \mathrm{O}$, recognizing water as life signifies that water is understood to be 'not only' $\mathrm{H}_{2} \mathrm{O}^{13}$ (cf. Boelens et al., 2016; De la Cadena, 2015). Rather it is a rice bowl, it is beauty and it is heritage, to name just a few (KESAN, 2015). Situated as it is, the SPP Charter states that it "finds its inspiration in the core of the indigenous Karen way of life, namely a worldview that sees land, forests, waters, and people, as inseparable." (Salween Peace Park Steering Committee and KNU, 2018:4). As such, nature-society relations are experienced as closely connected:

There won't be a forest when there is no more water ... and there also won't be water when the forest is gone ... when water and forest are gone, our community, our indigenous peoples cannot survive ... for these reasons, we want to conserve and protect our forests and rivers for our survival and for a sustainable existence for the next generation. (Saw Shee Nay Htoo in KESAN, 2017b)

In contrast with illustration 1 , it is explicitly emphasized that "we need to recognize river as a life, not as a commodity" (personal communication, 2017). Issues revolving around water are repeatedly communicated in metaphorical terms. 'Development' along the Salween River is described as "dark clouds [which] are hovering over the future of the Salween" and hydropower plants allegorized as "concrete monster [s]" (in Fawthrop et al., 2015). In these emotion-laden metaphors, an ontological situatedness that moves beyond water as $\mathrm{H}_{2} \mathrm{O}$ becomes graspable.

While the rallying call 'water is life' could be read as merely a catchy NGO slogan for advocacy, the SPP exemplifies that it is more than that. This is far from insisting on a romanticized notion of indigeneity (cf.

\footnotetext{
13 It is 'not only' $\mathrm{H}_{2} \mathrm{O}$ - this is far from implying that, what a Western understanding terms as 'science' is not of relevance within the SPP. Rather, it is to say that what can be revealed actually includes - but ultimately moves beyond - water's material and hydrological dimensions. This is noted in the SPP Charter, stating: "watersheds [are to be managed] with the use of Indigenous and scientific knowledge" (SPP Steering Committee \& KNU, 2018, p. 31) reflecting the partial connection of multiple worlds in De la Cadena's (2015) sense.
}

Forsyth \& Walker, 2008). The Salween River does carry more with it than mere $\mathrm{H}_{2} \mathrm{O}$ for its inhabitants. Providing a source of life (not only as drinking water but also in a spiritual sense, etc.) for the predominantly self-subsistent households is ultimately entwined with claims for self-determination and an inherent sense of belonging (Boelens et al., 2016).

The claims get further consolidated in the SPP's very own set of institutions, rules and regulations built around the KNU (i.e. KNU Land Policy) and the SPP Charter that incorporate inter alia customary rules that set claims for territorial articulations as well. This, for instance, proves true looking at the 'ownership' claims around water contradicting the 2008 Constitution's allocation of water under the ownership of the Union. Challenging the political authority of the Union Government, the KNU Land Policy states:

The ethnic nationalities are the ultimate owners of all lands, forests, water, water enterprises and natural resources. (KNU, 2015:5)

This claim brings with it a shift not just over the ownership of a material water $\mathrm{H}_{2} \mathrm{O}$ in a certain territorial unit of the Salween basin, but in claims about political authority, self-determination and life as it evolves along, around and through the Salween. It is such a situatedness, both ontologically and politically, that include the KNU's rather different ideas around territorial form, as well as internal tensions within the KNU between brigades with contrasting visions of the future of Kawthoolei (the land of the Karen). ${ }^{14}$ It is important to recognize that a unified, self-determined Kawthoolei is not self-evident. Relations within the $\mathrm{KNU}$ are too complex to draw out here, but in a simplified way two camps can be identified in relation to the peace negotiations: one restraining any cooperation with the Tatmadaw and in support of a political agreement before negotiating any major economic development, versus a pro-development camp that is " ... arguing that the KNU needs to be a central player in the region's economic development" (Jolliffe, 2017:n.p.). As such, the internal fragmentation of the KNU and its supporters further complicates peace-building. While the striving for peace is omnipresent, the strategies for achieving it vary greatly. The ideas around peace and (water) governance represented in the SPP, for instance, are not feasible for all $\mathrm{KNU}$ influenced territories. Jolliffe (2016:66) points out that in order to move towards peace

... the establishment of appropriate governance arrangements for the most autonomous parts of the northern KNU districts that constituted the Salween District under colonial administration [is crucial]. Having never been brought under centralized state rule, these areas [which today encompass the SPP] have long been at the heart of Karen nationalist narratives.

As such, it is no understatement that any framing of resource politics as being merely a Union/local issue misses the actual complexity in play.

It is important to acknowledge that while the SPP has enjoyed a fair amount of attention including in international media and through INGOs working in the region, the presence of the SPP is anything but secured. There have been recent renewed tensions between the Tatmadaw and the KNU in Mutraw district, representing conflicting claims for territorial and political authority (KHRG, 2019; KPSN, 2018). However, we would argue, even in the (currently unlikely) absence of those violent physical conflicts, there is much more at stake considering ongoing processes of state formation and ontological politics.

Considering the discussion introduced above, there is a risk that the SPP will be subsumed in the modern processes of state-formation, which would silence or side-line the ontological situatedness the SPP is

\footnotetext{
${ }^{14}$ According to Jolliffe (2016), territorial claims from within the KNU have, other than often claimed, never aimed at secession from the Union. However, the claims around 'Kawthoolei' emphasize the diverging territorial claims and associated power-relations with a call for more independence and that also cut through Karen society through different ideas of how to engage with the State.
} 
currently built upon. Far from insisting on a 'return' to any 'premodern' times, we suggest that the actors involved in the SPP will increasingly have to - and already do - engage in the field of tension where they need to negotiate the partially-connected worlds they are situated in. The 'modern Water' ontological grounding is especially powerful in its assertion of political authority. Thus, the ontological work to uphold a situatedness that would allow for more-than- $\mathrm{H}_{2} \mathrm{O}$ revealings to also be a part of future political processes will be crucial in negotiating whose voices count. As for now, the reality of the SPP becomes revealed through everyday practices of living within this territorial articulation and the practices connected to the formation of the SPP, and also through public attention created through press releases, media statements and academic publications engaging with it (including this one). Future work will need to show how power-relations within and across spaces will be renegotiated between actors holding different powers.

The SPP assembles a hydrosocial territory that represents a clearly demarcated, mapped area (KNU \& KESAN, 2016) and is thus able to steer a process of territorialization that shifts the Salween River to the center of attention (see Fig. 2). Furthermore, it connects to wider networks within and beyond Myanmar that share similar values manifesting territorial claims - whether it may be in the call to stop damming the Salween or in claims for self-determination of indigenous peoples. Yet, the fluidity of hydrosocial territories also becomes evident, for example acknowledging KESAN's (2008:7) observation that the border drawn between Thailand and Myanmar within the SPP area:

... until quite recently was not recognized by the indigenous Karen forest farmers who call both banks of the river their home. It looks simple enough, this border, when reading a map in Bangkok or Rangoon. But on the ground, this deep, fast, cold, narrow river ... has never been much of a border to the Karen. Language, customs, and land-use practices are common to both banks.

These interconnected and overlapping spatial articulations and experiences exemplify what Hoogesteger et al. (2016) identify as "territories-in-territory" describing the "coexistence of multiple territorial notions and contested construction processes" (Hoogesteger et al. 2016: 93).

Territorial claims around the SPP are distinctly based on historicallyrooted power relations. Mutraw District “... remains the most autonomous KNU-controlled region and has never been brought under centralized state rule" (Jolliffe, 2016, p. 9). After independence, power relations shifted several times not only between the KNU and Union Government, but also amongst different KNU districts (Brenner, 2017). During the 1990s, Mutraw District gained power as other districts lost influence due to declining economic trade with Thailand and strong interventions by the Tatmadaw. Those power struggles, according to Brenner, led to today's factions within the KNU. The proposed SPP is located in this still very much autonomous region, covering a majority of today's Mutraw District, and indicating that the extent of today's SPP is anything but coincidental. Rather, it emerges from past and present environment-making processes. This shows how political authority does not operate as a simple one-way assertion of certain claims but evolves out of a historically-rooted hydrosocial assemblage of water flows, supporting and opposing actors, historical-political evolvements, discourses, and processes of environment-making that are situated in different (water) ontologies.

The SPP is less a fixed territory than a process of territorialization. KESAN (2017a) states:

The Salween Peace Park development process continues to work towards international recognition-cooperating with Thailand's adjacent Salween National Park and Salween National Wildlife Sanctuary. Once formally established, the initiative will engage the Myanmar national government in discussions as to how to best protect the reserve and maximize its public benefit.
This indicates the (re)production of political authority within the assemblage spanning around the SPP, but simultaneously emphasizes the fluidity of territorialization processes. The SPP is said to be built on long-established relations within the area (personal communications, 2017). The 'naming' of the SPP, which emerged in 2015 , is an attempt to render visible subsisting practices (and their ontological situatedness) that have long existed, which is to be reworked and performed within Myanmar's current political context and associated discursive spheres, including meetings where SPP proponents encounter representatives of the NWRC on rare occasion. The naming and declaration, furthermore, is in part also a strategic approach to put community in the center of peace negotiations (personal communication, 2018).

\subsection{Illustration 3: The ontological politics of Salween mainstream dams}

A large hydropower dam is a complex assemblage of multi-scaled human-more-than-human relationships, including technologies ranging from concrete infrastructure to high-voltage transmission lines; and hydrological, geological, and ecological biophysical relationships (Boelens et al., 2016; Sneddon, 2015). Also significant are the diverse forms of knowledges and associated institutions involved, including scientific and indigenous forms of knowledge, and their associated discourses and power relations. In this section, we consider plans for large dams on the Salween River as the sites of ontological politics, where the performances of multiple ontologies collide and are rendered visible in a high-stake contestation. The construction of a dam may deepen the dominance of modernist ontologies, whilst serving to marginalizing other ontologies. Furthermore, a large dam is a major reconfiguration of human-more-than-human relationalities that reorganizes hydrosocial territories (Hommes \& Boelens, 2017; Moore, 2015).

Plans for hydropower dams on the Salween River mainstream backed by the Thai and Myanmar governments have existed at least since the late 1970s, but gained momentum post-1988 as Myanmar began opening-up to foreign investment from China and Thailand (Magee \& Kelley, 2009). At present, there are seven mainstream dams in Myanmar at various stages of planning, mostly intended as power export projects to Thailand and China (Middleton, Scott, \& Lamb, 2019). There are, furthermore, nine large dam projects planned or under construction on five major tributaries, in addition to the four already in operation. Whilst full-scale construction of the mainstream Salween dams is yet to be initiated, preparatory work has been undertaken including field site investigations, public consultations, and in some cases preliminary construction work that have already resulted in community resettlement, heightened tensions, and other impacts such as logging.

For the cascade as a whole, Thailand's state-owned electricity utility, the Electricity Generating Authority of Thailand (EGAT), has played a key role in commissioning expert studies since the late 1970s proposing the Salween dams as power import projects. They rationalize the projects as needed to ensure Thailand's electricity security in terms of supply and affordability, for domestic consumers and industrialization and economic growth (Magee \& Kelley, 2009). This approach to electricity is consistent with a modernization ontology of Water discussed in illustration 1. Even as there has been a slight increase in 'public participation' in electricity planning in Thailand and more attention paid to 'renewable electricity,' such as solar power as part of a 'sustainable electricity transition' (Delina, 2018), this public participation is scoped so as to legitimize modernization rather than fundamentally challenge it.

In pursuit of the Salween dams, EGAT and the Thai Government have collaborated with the Union Government of Myanmar, and in particular the Ministry of Electricity and Energy (MOEE; previously the Ministry of Electric Power 2). The project developers, meanwhile, are state-owned enterprises and private firms from Thailand, China and Myanmar, including EGAT International, PowerChina, and China Datang, together with domestic conglomerates such as the International Group of Entrepreneurs (Middleton et al., 2019). The locations of the projects are in 


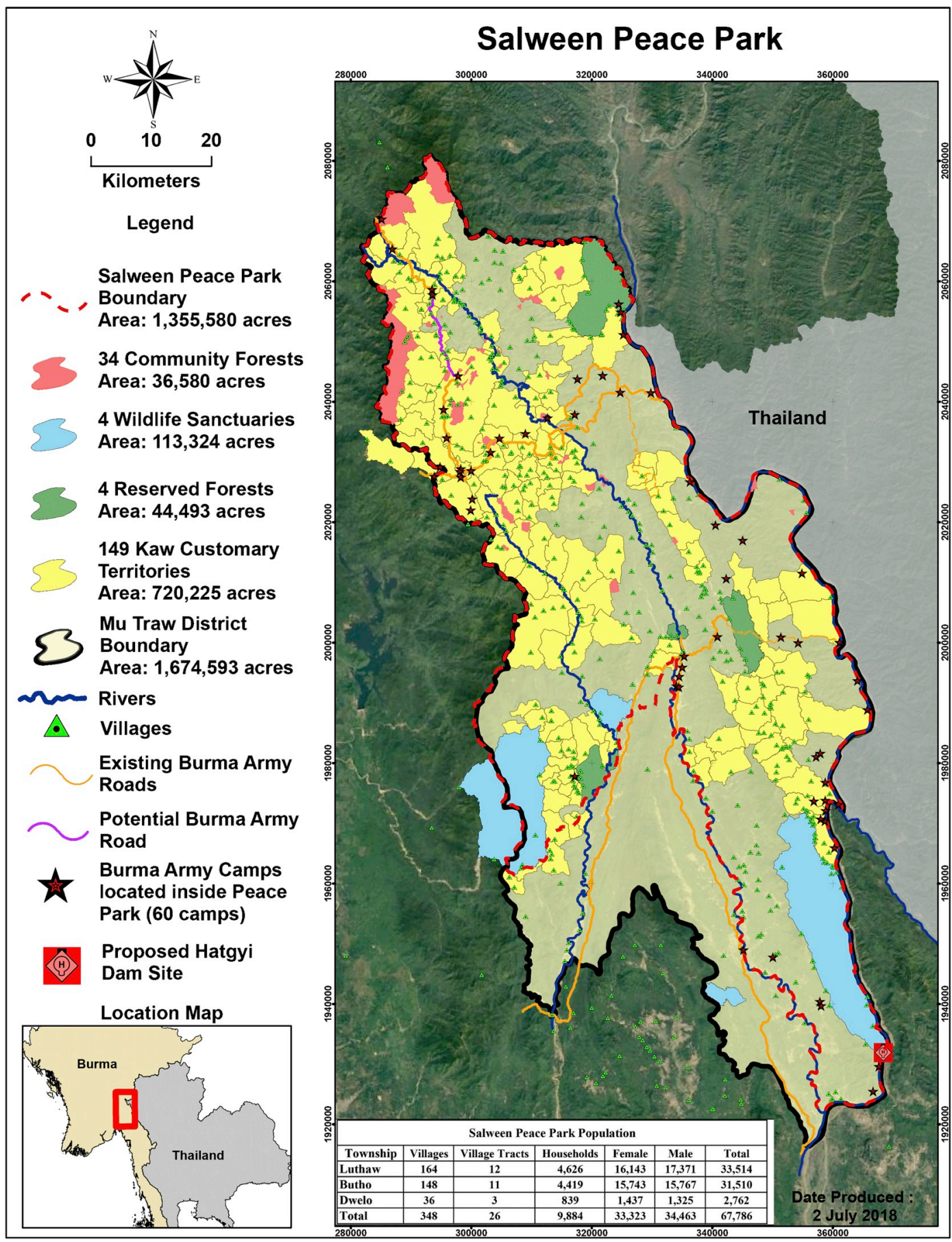

Fig. 2. Map of the Salween Peace Park and selected features as of July 2018. (Reproduced from KESAN, with permission).

areas where the Union government's political authority and legitimacy is contested by EAOs, and where violent conflict occurs (Burke et al., 2017). Thus, the Tatmadaw and various allied Border Guard Forces and paramilitaries, as well as the EAOs, are also key actors in the history of each project.

Plans for the Salween River mainstem dams and regional electricity trade have been formulated within the context of the Asian Development
Bank's (ADB) inter-governmental Greater Mekong Subregion (GMS) program for economic integration (and modernization), launched in 1992, that incorporates mainland Southeast Asia and Southwestern China. ${ }^{15}$ Via regional intergovernmental meetings and agreements, commissioned studies, and various resultant hard and soft infrastructure projects, the GMS program has accelerated regional economic integration, in the process expanding capitalism across the region and

\footnotetext{
15 Since the GMS, there have been numerous other regional economic plans, including the Thailand-led Ayeyarwady-Chao Phraya-Mekong Economic Cooperation Strategy (ACMECS) and the China-led Lancang-Mekong Cooperation Strategy.
} 
embedding it into the global economy (Glassman, 2010). The naturalization and territorialization of the GMS as a region are closely associated with a modernization ontology that views major transboundary rivers as 'development resources' (Hirsch, 2016).

As Hommes, Boelens, and Maat (2016, p. 11) state, “... so-called 'integrated' or 'hydraulic' projects are in fact means to configure and re-configure hydrosocial territories, altering the physical-ecological, socio-economic, cultural-symbolic and political spaces where they are realized." If the Salween River is to be impounded by hydropower dams, it is to be tied to the wider GMS region via a grid of transmission lines and in a relationship of cross-border electricity trade. Thus, Water is to be rendered commodified, and its enclosure and control a source of profit. This defining of water as commodifiable to produce hydroelectric power is indeed ontological work, undertaken by the actors outlined above through domestic water, energy, and economy planning processes in Thailand and Myanmar, and within the institutions of the GMS. Furthermore, new hydrosocial territories emerge when infrastructure operation is shaped by electricity demand in large urban centers mainly outside the watershed - including in Thailand and China - changing river hydrology (and other socio-biophysical processes) in the process (Hommes, Boelens, Harris, \& Veldwisch, 2019). Thus, watersheds are to be reterritorialized adding 'powersheds' as yet another territorial articulation as the Salween mainstream dams, embedded in a regional transmission grid, create new human-more-than-human relationships that network beyond the ethnic areas where the projects are located, and also beyond the Salween basin watershed and the political border of Myanmar (Middleton \& Allouche, 2016).

At the project scale, another hydrosocial territory emerges, given that infrastructure construction projects require - and are thus intimately tied to - territorial control. Conflicts in the region of some proposed hydropower sites are at least partially related to 'securing' the dam site, necessary for construction to proceed. For example, recent fighting between the Democratic Karen Buddhist Army (DKBA) and the Tatmadaw-allied Border Guard Force has sporadically broken out around the Hatgyi Dam site and has been linked by NGO observers to plans for the project (Hein Ko Soe, 2016). More broadly, it has been suggested by some civil society observers and EAOs that the Salween dams are also about the Union Government asserting control over territory and 'governing' people through dispossession and flooding of lands with the implication that Internally Displaced People and refugees currently in Thailand cannot return to their original lands (Stokes, 2016). This is suggestive of a process of governmentalizing hydrosocial territories (Boelens et al., 2016) that acts to marginalize contesting groups and thus marginalize certain ontological groundings too.

Plans for large dams have evoked local and transnational civil society networks and social movements to challenge them (Simpson, 2013). Before 2010, in Myanmar under the military junta government, it was difficult for ethnic communities and civil society domestically to directly challenge the projects, or to engage with the government on any issue of public concern (Farrelly et al., 2018). Rather, a transnational civil society movement resisted the projects. Many groups were based in Thailand, and covertly coordinated with some ethnic community leaders in Myanmar. This movement involved global mobilizations highlighting the human rights violations of the junta government towards ethnic communities related to plans for the Salween dams, and celebrating the ecological value of the river and highlighting its connection to riparian livelihoods. For instance, in February 2007, a "Global Day of Action Against the Salween Dams in Burma" took place in 19 cities globally. A large number of NGO studies were also published that ranged from strong critique of human rights violations to research revealing the ecological diversity and ethnic livelihood practices in the Salween basin (Lamb et al., 2019). Thus, a global discursive hydrosocial territory of the Salween has been produced.

Since the transition to a semi-civilian government in Myanmar after 2010, whilst transnational campaigns have continued, there has been an increased discursive engagement within Myanmar (Bright, 2019; Götz,
2019; Middleton et al., 2019). One locus has been amongst the villages along the Salween River, which have also networked with ethnic-NGOs. For example, in Karen State, the NGO KESAN has worked in and with KNU-controlled areas to establish the SPP (illustration 2). The SPP relates to the proposed Hatgyi Dam, given that it is planned to be located immediately downstream of the SPP on the border of Hpa-An and Mutraw districts (cf. Fig. 2), ${ }^{16}$ and the reservoir would extend into it. KESAN also operates in Union Government-controlled territories $80 \mathrm{~km}$ downstream of the proposed Hatgyi Dam to establish community-based resource governance projects that emphasize more localized, community-centered forms of 'development' and Karen cultural practices (Bright, 2019; KESAN, 2018).

This primarily local-national movement, formed of the actors around the SPP that connect to a wider network of CSOs and grassroots activists of the anti-dam movement within the region and beyond gives a stark 'no' to large-scale hydropower construction:

"We don't agree with the Hat Gyi dam and will never allow it to be built. The [Salween] is our identity and we don't want to destroy our identity" (Saw Thar Bo in Hein Ko Soe, 2016)

When the Government see the Salween, they [don't] see the beauty ... but they just see the profits. When I close my eye[s], I can see the beauty of the Salween River. Salween River is very important, is very precious for me, I think. Not only me, but also like other ethnics like Shan, Karenni, Mon, like millions of people. So, I want to tell the world that Salween is not for sale. (in Fawthrop et al., 2015)

These quotes hint towards a performance of a very different ontology to that of the NWRC (illustration 1) and is productive of a hydrosocial territory that ties together the livelihoods and riverside spatialities of the Salween River. We would argue that this may not just represent a different view on/opinion about the Salween and possible large dam projects, but a totally different starting point, namely an ontological situatedness that moves through 'identity' rather than technomanagerial expert knowledge.

In the case of hydropower, since Myanmar's transition to a semicivilian government, a growing number of public participation exercises have been hosted by the government that would appear to allow input of diverse perspectives (and performed ontologies). Construction companies are looking for profit, governments for energy supply or irrigation for the country, and ethnic communities are worried about their livelihoods and self-determination. These debates are often portrayed as differences of opinion, rather than more fundamentally a potential ontological politics between contesting worldings. The mode of public participation fits neatly into the dominant modernist ontology as differences of opinion and perspectives do not challenge the modernist debate of a universal and single reality (Blaser, 2009). In other words, similar to illustration 1 with regard to public participation within IWRM, apparent accommodation of multiple ontologies as mere perspectives can in fact be a means for the affirmation of a modern ontology and the marginalization of other ontologies (Swyngedouw, 2013).

For example, the Mongton Dam in Shan State incorporated public consultations for its EIA, which were widely regarded as a sham by riverside communities and allied civil society groups. In another example, the IFC's SEA of Myanmar's hydropower sector involved wide public consultation (IFC, 2018). From this study, and linked to a wider regional and global trend, has emerged the concept of 'sustainable hydropower', which is an expert-led discourse that large dams can be built better with less social impacts (Middleton, 2018). 'Sustainable hydropower' reflects the most recent iteration of a modern ontology rooted in the language of inclusive and sustainable development. But what if there

\footnotetext{
${ }^{16}$ Hpa-An District is one of seven districts designated under the KNU system, distinct from the Myanmar Government system which designates Karen State as Kayin State, dividing it into seven townships.
} 
is more at stake? What if the energy gained through a certain amount of $\mathrm{H}_{2} \mathrm{O}$ held back by the planned Salween dams are just not commensurable with/equal to the water that constitutes various other assemblages of the river, such as the Daw La Lake in Karen State, or the ecologically-renowned Kunhing (Thousand Islands) complex on the Nam Pawn River in Shan State. ${ }^{17}$ In other words, what if water is not only a resource $\mathrm{H}_{2} \mathrm{O}$ but gets enacted within multiple ontologies?

\section{Conclusion: Multiple ontologies and state formation}

The Salween is $\mathrm{H}_{2} \mathrm{O}$, but "not only" that (to borrow from Mariano Turpo as cited by De la Cadena, 2015). Throughout this paper, we have sought to draw out how multiple ontologies of the Salween become enacted - or, at least, what can be grasped of them in terms of their human-more-than-human relationalities. Our emphasis on how multiple ontologies of water are performed has allowed us to reveal the continuous making and unmaking of networks of human-more-than-human relationalities that constitute these hydrosocial assemblages, rather than seeking to (futilely) name what each ontology ultimately is. We have emphasized the agency and contestation of a range of actors, including the Myanmar Union government; the Tatmadaw; EAOs; domestic and foreign private investors; local, national and transnational civil society groups; and community members. In the three illustrations presented, instead of dismissing the modern revealing of Water as mere fallacy, we have examined its enactment through a network of powerful actors as ontological work, and its agenda as ontological politics to manifest a dominant modernist paradigm and marginalize other worldings. The implications include, for example, the legitimization of large-scale dam construction through a techno-managerial approach to Water Resources.

By opening up a conversation conceptually combining insights around multiple ontologies with the lens of hydrosocial territorialization, we have sought to shed light on the wider political processes of state formation. 'The Union,' as claimed by Myanmar's central government, is largely a de jure claim now reflected in the 2008 Constitution that encompasses a national and sub-national system of governance with a limited measure of decentralization (cf. Agnew, 2005). However, de facto administration in ceasefire and conflict areas reflects a complex mosaic of claims for political authority, which is a key - and thorny question for the ongoing peace negotiations (South, 2018; Walton, 2018). We have shown how ontological politics around multiple waters are productive of multiple overlapping, partially-connected hydrosocial territories, which are, as Hoogesteger et al. (2016) observe, 'territories-in-territory.' These hydrosocial territories constitute one of various spatiotemporal processes that is co-productive of contested sovereignties in the Salween basin. The stabilization of territory, and in particular the claims for legitimacy that partially ground assertions of political authority, also entail ontological work to naturalize the particular ontology associated with a territorial claim. The interdependence between partially-connected worlds and 'territories-in-territory' point towards the complexity of processes (and its analysis) in play. We propose that further research should continue to explore the kinds of actors and everyday forms of contestation surrounding 'ontological politics' in the Salween. We especially encourage further work on more localized power relations of heterogeneous actors within seemingly homogenous groups such as EAOs or certain communities.

\footnotetext{
17 We take Daw La Lake and the Kunhing complex as two localities on the Salween River where local communities have long practiced livelihoods distinct from a modernist water ontology. Daw Lar Lake supports the fishing and agriculture of 8000 Karen people, and is governed through local customary arrangements (Bright, 2019). In the Kunhing complex, a number of ethnic groups depend on the complex's river and forest ecosystem for their livelihoods (Action for Shan Rivers, 2016). Until recently, there was armed conflict in the area, whilst at present, it is an area of complex mixed administration.
}

With 'natural resource sharing' high on the agenda in Myanmar's peace negotiation process, debates tend to frame Natural Resources as something that needs to be 'governed', 'managed', and 'shared' by and amongst society within and amongst certain territories (Burke et al., 2017). In this context, water predominantly becomes enacted and revealed through a 'modern' conceptualization of $\mathrm{H}_{2} \mathrm{O}$ - but as we have demonstrated throughout this paper, it is 'not only' such. The actors involved in the peace negotiations and thereby in attempts of state-formation and the networks they are connected to/relate themselves to need to be seen as acting based on multiple/different ontologies when talking about 'resources'. In other words, they need to be understood as situated within their respective ontologies (cf. Joronen \& Häkli, 2016). In the case of the Salween basin, the stakes for the dominance of one ontology and the marginalization of others are high, given their association with claims for political authority, legitimacy and territory within Myanmar's ongoing peace negotiations. We do not claim that this article offers a roadmap for peace in the country. Our work does suggest, however, that if multiple ontologies of 'resources' such as water are not acknowledged, it is unlikely that a satisfactory agreement conducive to sustained peace will be achieved.

\section{Declaration of competing interest}

None.

\section{Acknowledgements}

This research was partly supported by the CGIAR Water-LandEcosystem (WLE) Mekong program. We sincerely thank our informants and partners for their invaluable insights, Alec Scott for reviewing an early manuscript, and Vanessa Lamb, Orapan Pratomlek, and Saw John Bright for their general support. We also thank the three anonymous reviewers of this paper, whose suggestions substantially improved the paper.

\section{References}

Action for Shan Rivers. (2016). New film: Shan state's unique "thousand Islands" under threat from Salween dam plans. https://www.shanhumanrights.org/eng/index.php/ 307-new-film-shan-state-s-unique-thousand-islands-under-threat-from-salween-da m-plans.

Agnew, J. (2005). Sovereignty regimes: Territoriality and state authority in contemporary world politics. Annals of the Association of American Geographers, 95, 437-461.

Aye Sapay Phyu. (2016). Re-launched committee to manage water resources. The Myanmar Times, 11.07.2016 http://www.mmtimes.com/index.php/national-news/21308-relaunched-committee-to-manage-water-resources.html.

Bakker, K. (2007). The "commons" versus the "commodity": Alter-globalization, antiprivatization and the human right to water in the global south. Antipode, 39, 430-455. https://doi.org/10.1111/j.1467-8330.2007.00534.x.

Barnes, J., \& Alatout, S. (2012). Water worlds: Introduction to the special issue of social studies of science. Social Studies of Science, 42, 483-488. https://doi.org/10.1177/ 0306312712448524.

Blaser, M. (2009). Political ontology: Cultural studies without 'culture'? Cultural Studies, 23, 873-896. https://doi.org/10.1080/09502380903208023.

Blaser, M. (2013). Ontology and indigeneity: On the political ontology of heterogeneous assemblages. Cultural Geographies, 21, 49-58. https://doi.org/10.1177/ 1474474012462534

Blaser, M., \& De la Cadena, M. (2018). Pluriverse: Proposal for a world of many worlds. In M. De la Cadena, \& M. Blaser (Eds.), A world of many worlds (pp. 1-22). Durham: Duke University Press.

Boelens, R., Hoogesteger, J., Swyngedouw, E., Vos, J., \& Wester, P. (2016). Hydrosocial territories: A political ecology perspective. Water International, 41, 1-14. https://doi. org/10.1080/02508060.2016.1134898.

Brenner, D. (2017). Inside the Karen insurgency: Explaining conflict and conciliation in Myanmar's changing borderlands. Asian Security, 1-17. https://doi.org/10.1080/ 14799855.2017.1293657.

Bright, S. J. (2019). Rites, rights and water justice in Karen state: A case study of community-based water governance and the Hatgyi dam. In C. Middleton, \& V. Lamb (Eds.), Knowing the Salween River: Resource politics of a contested transboundary river (pp. 71-86). Cham: Springer.

Burke, A., Williams, N., Baroon, P., Jolliffe, K., \& Carr, T. (2017). The contested areas of Myanmar: Subnational conflict, aid, and development (San Francisco).

De la Cadena, M. (2015). Earth beings: Ecologies of practice across Andean worlds. Durham: Duke University Press. 
Delina, L. L. (2018). Whose and what futures?: Navigating the contested coproduction of Thailand's energy sociotechnical imaginaries. Energy Research \& Social Science, 35, 48-56.

Directorate of Water Resources and Improvement of River Systems (DWIR). (2015). Proposed national water framework directive.

Farrelly, N., Holliday, I., \& Simpson, A. (2018). Explaining Myanmar in flux and transition. In A. Simpson, N. Farrelly, \& I. Holliday (Eds.), Routledge handbook of contemporary Myanmar (pp. 3-12). New York: Routledge.

Fawthrop, et al. (2015). Saving the Salween river. Karen Environmental and Social Action Network (KESAN) \& Eureka Film. https://www.youtube.com/watch?v=eO -w1ZyEXMY.

Ferguson, J. (1994). The anti-politics machine: "Development" and bureaucratic power in Lesotho. The Ecologist, 24, 176-181.

Forsyth, T., \& Walker, A. (2008). Forest guardians, forest destroyers: The politics of environmental knowledge in northern Thailand. Culture, place, and nature. Seattle: University of Washington Press.

Glassman, J. (2010). Bounding the Mekong: The Asian Development Bank. China, and Thailand: University of Hawai'i Press.

Global Water Partnership (GWP). (2016). Myanmar water partnership. https://www.gwp. org/en/GWP-South-East-Asia/PARTNER/Country-Water-Partnerships/myanmar-wa ter-partnership/. (Accessed April 2018).

Götz, J. M. (2019). Contested water governance in Myanmar/Burma: Politics, the peace negotiations and the production of scale. In C. Middleton, \& V. Lamb (Eds.), Knowing the Salween River: Resource politics of a contested transboundary river (pp. 87-106). Cham: Springer.

Hein Ko Soe. (2016). Activists damn Salween plans. Frontier Myanmar, 20.10.2016 https ://frontiermyanmar.net/en/activists-damn-salween-plans.

Hirsch, P. (2016). The shifting regional geopolitics of Mekong dams. Political Geography, 51, 63-74. https://doi.org/10.1016/j.polgeo.2015.12.004.

Hommes, L., \& Boelens, R. (2017). Urbanizing rural waters: Rural-urban water transfers and the reconfiguration of hydrosocial territories in Lima. Political Geography, 57, 71-80. https://doi.org/10.1016/j.polgeo.2016.12.002.

Hommes, L., Boelens, R., Harris, L. M., \& Veldwisch, G. J. (2019). Rural-urban water struggles: Urbanizing hydrosocial territories and evolving connections, discourses and identities. Water International, 44(2), 81-94.

Hommes, L., Boelens, R., \& Maat, H. (2016). Contested hydrosocial territories and disputed water governance: Struggles and competing claims over the Ilisu Dam development in southeastern Turkey. Geoforum, 71, 9-20. https://doi.org/10.1016/ j.geoforum.2016.02.015.

Hoogesteger, J., Boelens, R., \& Baud, M. (2016). Territorial pluralism: Water users' multi-scalar struggles against state ordering in Ecuador's highlands. Water International, 41, 91-106. https://doi.org/10.1080/02508060.2016.1130910.

International Finance Corporation (IFC). (2018). Strategic environmental assessment (SEA) of the Myanmar hydropower sector. Washington, DC: IFC.

Jolliffe, K. (2016). Ceasefires, governance and development: The Karen National Union in times of change.

Jolliffe, K. (2017). A new chapter for the Karen movement. Frontier Myanmar, 26.04.2017 http://frontiermyanmar.net/en/a-new-chapter-for-the-karen-movement.

Joronen, M., \& Häkli, J. (2016). Politicizing ontology. Progress in Human Geography, 41, 561-579.

Karen Environmental and Social Action Network (KESAN). (2008). Khoe Kay: Biodiversity in peril. Chiang Mai: Wanida Press.

Karen Environmental and Social Action Network (KESAN). (2015). No Salween dams: Karen message on international day of action for rivers and against dams. https://www. youtube.com/watch? $\mathrm{v}=$ eW3F9RaxBqY.

Karen Environmental and Social Action Network (KESAN). (2017). Conserving protected indigenous Karen landscape. Press Release.

Karen Environmental and Social Action Network (KESAN). (2017). The Kheshorter: Indigenous Karen's community forest. https://www.youtube.com/watch? $\mathrm{v}=\mathrm{rE}$ xDGb5jpOU.

Karen Environmental and Social Action Network (KESAN). (2018). Community based water governance: A briefing report on Daw Lar Lake.

Karen Human Rights Group (KHRG). (2019). Hpapun Situation Update: Tatmadaw road construction activities results in skirmishes with the KNLA and displacement in Lu Thaw Township. http://khrg.org/2019/01/18-63-s1/hpapun-situation-update-tatmadaw-r oad-construction-activities-results-skirmishes. (Accessed 15 April 2019).

Karen National Union (KNU). (2015). Karen national union - KNU land policy.

Karen National Union (KNU), \& Karen Environmental and Social Action Network (KESAN). (2016). Salween peace Park: A vision for an indigenous Karen landscape of human-nature harmony in southeast Myanmar. Flyer.

Karen Peace Support Network (KPSN). (2018). The nightmare returns: Karen hopes for peace and stability dashed by Burma Army's actions.
Lamb, V., Middleton, C., Bright, J., et al. (2019). A State of knowledge of the Salween River: An overview of civil society research. In C. Middleton, \& V. Lamb (Eds.), Knowing the Salween River: Resource politics of a contested transboundary river (pp 107-120). Cham: Springer.

Li, T. M. (2000). Articulating indigenous identity in Indonesia: Resource politics and the tribal slot. Comparative Studies in Society and History, 42(1), 149-179.

Linton, J. (2010). What is water? The history of a modern abstraction $\left(1^{\text {st }}\right.$ ed.). Vancouver: UBC Press. Nature | History | Society Series.

Linton, J., \& Budds, J. (2014). The hydrosocial cycle: Defining and mobilizing a relational-dialectical approach to water. Geoforum, 57, 170-180. https://doi.org/ 10.1016/j.geoforum.2013.10.008.

Magee, D., \& Kelley, S. (2009). Damming the Salween. In F. Molle, M. Käkönen, \& T. Foran (Eds.), Contested waterscapes in the Mekong region: Hydropower, livelihoods and governance (pp. 115-140). London, Sterling, VA: Earthscan.

Middleton, C. (2018). Branding dams: Nam Theun 2 and its role in producing the discourse of "sustainable hydropower. In B. Shoemaker, \& W. Robichaud (Eds.), Dead in the water: Global lessons from the world Bank's model hydropower project in Laos Madison (pp. 271-292). University of Wisconsin Press.

Middleton, C., \& Allouche, J. (2016). Watershed or powershed?: Critical hydropolitics, China and the 'Lancang-Mekong cooperation framework'. The International Spectator, 51, 100-117. https://doi.org/10.1080/03932729.2016.1209385.

Middleton, C., \& Lamb, V. (Eds.). (2019). Knowing the Salween River: Resource politics of a contested transboundary river. Cham: Springer.

Middleton, C., Scott, A., \& Lamb, V. (2019). Hydropower politics and conflict on the Salween river. In C. Middleton, \& V. Lamb (Eds.), Knowing the Salween River: Resource politics of a contested transboundary river (pp. 27-48). Cham: Springer.

Mol, A. (1999). Ontological politics. A word and some questions. The Sociological Review, 47, 74-89. https://doi.org/10.1111/j.1467-954X.1999.tb03483.x.

Molle, F. (2008). Nirvana concepts, narratives and policy models: Insights from the water sector. Water Alternatives, 1, 131-156.

Moore, J. W. (2015). Capitalism in the web of life: Ecology and the accumulation of capital. New York: Verso.

National Water Resources Committee (NWRC). (2015). Myanmar national water policy. NWP.

Nesheim, I., \& Platjouw, F. M. (2016). Framework notes and recommendations for integrated water resources management in Myanmar. Oslo.

Obertreis, J., Moss, T., Mollinga, P., \& Bichsel, C. (2016). Water, infrastructure and political rule: Introduction to the special issue. Water Alternatives, 9(2), 168-181.

Robbins, P. (2012). Political ecology ( $2^{\text {nd }}$ ed.). Chichester: Wiley-Blackwell.

Salween Peace Park Governing Committee (SPP GC). (2019). Statement on the first session of the Salween peace Park general assembly: 5th April 2019.

Salween Peace Park Steering Committee, \& Karen National Union (KNU). (2018). Charter of the Salween peace Park.

Simpson, A. (2013). Challenging hydropower development in Myanmar (Burma): Crossborder activism under a regime in transition. The Pacific Review, 26, 129-152. https://doi.org/10.1080/09512748.2012.759264.

Sneddon, C. (2015). Concrete revolution: Large dams, cold war geopolitics, and the US Bureau of Reclamation. London: University of Chicago Press.

South, A. (2018). 'Hybrid governance' and the politics of legitimacy in the Myanmar peace process. Journal of Contemporary Asia, 48, 50-66. https://doi.org/10.1080/ 00472336.2017.1387280.

Stokes, D. (2016). Fire on the Salween: Dams in conflict zones could threaten Myanmar's fragile peace process. Mongabay News, 01.12.2016 https://news.mongabay.com/ 2016/12/fire-on-the-salween-dams-in-conflict-zones-could-threaten-myanmars-fra gile-peace-process/.

Swyngedouw, E. (2004). Social power and the urbanization of water: Flows of power. New York: Oxford University Press.

Swyngedouw, E. (2013). UN water report 2012: Depoliticizing water. Development and Change, 44, 823-835. https://doi.org/10.1111/dech.12033.

Union of Myanmar. (2008). The constitution of the Republic of the union of Myanmar.

Walton, M. J. (2018). Nation-building. In A. Simpson, N. Farrelly, \& I. Holliday (Eds.), Routledge Handbook of contemporary Myanmar (pp. 393-403). London and New York: Routledge.

Warner, J., Wester, P., \& Bolding, A. (2008). Going with the flow: River basins as the natural units for water management? Water Policy, 10, 121. https://doi.org/ 10.2166/wp.2008.210.

Wesselink, A., Kooy, M., \& Warner, J. (2017). Socio-hydrology and hydrosocial analysis: Toward dialogues across disciplines. Wiley Interdisciplinary Reviews: Water, 4, e1196. https://doi.org/10.1002/wat2.1196.

Yates, J. S., Harris, L. M., \& Wilson, N. J. (2017). Multiple ontologies of water: Politics, conflict and implications for governance. Environment and Planning D: Society and Space, 35, 797-815. https://doi.org/10.1177/0263775817700395. 